\title{
Distribution of Credit Linkage Program to Cooperatives Facing a Competitive ASEAN Economic Community
}

\author{
John Latumeten ${ }^{1}$, *Ujang Badru Jaman ${ }^{2}$, Endah Pertiwi ${ }^{3}$ \\ ${ }^{1}$ Lecrture in Nusa Putra University, Sukabumi, Indonesia \\ ${ }^{2}$ Lecrture in Nusa Putra University, Sukabumi, Indonesia \\ ${ }^{3}$ Lecrture in Nusa Putra University, Sukabumi, Indonesia \\ *Corresponding author. E-mail: Ujang.badru@nusaputra.ac.id
}

\begin{abstract}
This study examines the implementation of the Linkage Program as access to MSMEs banking credit and to find and formulate arrangements to increase the competitiveness of MSMEs in facing the MEA. Legal entities formed collectively by the community in collaboration with the Regional Government in coaching and funding. It increases competitiveness so that domestic products can compete with foreign products. Cooperatives have a fundamental role in promoting economic independence and have become the mainstay of the lower middle class of society in improving the community's economic welfare. The cooperative is given a loan directly by the bank to finance its members until the joint is large and can provide loans to banks. The method used for writing this journal is normative juridical. The type of normative legal research is research aimed at assessing the quality of the legal norms themselves, so normative legal research is often classified as qualitative research, with the object of research being cooperatives. Cooperatives prefer financing cooperation with SOEs through the Partnership Development scheme. The interest offered is lower than banks, no administrative fees are charged, and administration is more straightforward than banking. In addition, the Government can seek through a Quadro Helix approach involving the Government, Academics, Private Sector, and Community to increase the competitiveness capacity of the Cooperative.
\end{abstract}

Keywords: Cooperatives, Linkage Program, ASEAN Economic Community (AEC), Quadro Helix.

\section{INTRODUCTION}

The provisions of Article 33 of the 1945 Constitution clearly stated that Article 33 is the only article that is the basis of the Indonesian economy; therefore, the formation of economic law must refer to Article 33 of the 1945 Constitution, because that article contained in the constitution which is the highest legal basis, the consequences are binding or have a must/imperative, meaning that it cannot be ruled out under any circumstances. Article 33 of the 1945 Constitution, the Indonesian economy is based on economic democracy. This means that the financial system, the objectives to be achieved, economic development, policies, and programs are all based on the principle of economic democracy. This shows that production is carried out by all, for all, and under the leadership of ownership by community members. The welfare of the community is prioritized, not a handful of people. Therefore, the production branches that are important for the state and affect the people's livelihood must be controlled by the state [1].

The economic sector emphasizes development, which impacts the development of businesses in Indonesia, both large companies, medium businesses, and small businesses, even microbusinesses. The implementation of economic development and aiming to increase national income are also aimed at accelerating employment growth and reducing unemployment. Therefore, all of the potential and capabilities of the capital owned must be utilized in such a way as to be maximally accompanied by policy measures from the government to guide, assist growth, and to improve even greater capabilities, especially for small entrepreneurs so that they can actively participate in 
development. According to [2], "Micro, Small and Medium Enterprises (MSMEs) is a manifestation of the economic life of the majority of the Indonesian people so that they can be said to be an integral part of the national business world which has a position of potential, and a significant and strategic role in realizing national development goals in general, especially economic development. MSMEs are the sector that plays the most role in developing the national economy and providing general economic services to the community and play a role in realizing national stability. Realizing how important MSMEs are, it is not surprising why governments in all developing countries including Indonesia have policies, with subsidized credit schemes as the most important component, to support the development and growth of MSMEs".

MSMEs play a significant role in job creation and economic growth, both national and regional. The development and empowerment of MSMEs are one of the government's efforts to reduce the economic disparity of the community to realize an increase in people's welfare. MSMEs have their advantages, one of which is that the business is not a formal sector business. So, it does not need a permit like a legal company.

The existence of MSMEs should not be doubted, considering that they absorb a lot of workers who have proven to be able to survive during the economic crisis and become the driving force of the economy. MSMEs are also often associated with alleviating economic and social problems, such as high poverty levels, significant unemployment, inequality in income distribution, and uneven development processes. The existence of MSMEs is expected to make a significant positive contribution to efforts to overcome these problems.

The success of MSMEs, which are the business group with the most significant number and is quite dominant in the economy, will significantly affect the achievement of the success of the ASEAN Economic Community (from now on referred to as "MEA"). ASEAN member countries have prepared the ASEAN Economic Community for a long time to be established in 2015. The AEC, as stated in the blueprint for its establishment (ASEAN Economic Community Blueprint), aims to make ASEAN a production base and single market region (pillar 1), regional competitive areas (pillar 2), areas that prioritize development (pillar 3) and areas that are integrated with global markets (pillar 4). The four pillars are interrelated and mutually support one another. ASEAN as a single market and production base is then divided into five core elements, namely (i) free flow of goods; (ii) free flow of services; (iii) free flow of investment; (iv) free flow of capital; (v) free flow for skilled workers.

The AEC Blueprint 2025 reaffirms the role of MSMEs as the backbone of the ASEAN economy. Strengthening MSMEs is one of the essential elements in the 2015 AEC Blueprint, particularly related to realizing a competitive region (pillar 2) for equitable economic development, which is essentially ASEAN's commitment to reducing development gaps in the area. Through the AEC Blueprint 2025, ASEAN places a new emphasis on the development and promotion of MSMEs and prepares various more structured programs to enhance the competitiveness and resilience of MSMEs further to take advantage of ASEAN's economic integration.

According to [3], "MSMEs themselves have a problem that becomes an obstacle in the development of the business, namely having difficulty in getting credit from banks. Considering that banks in providing credit apply the prudent banking principle or known as the 5C Principle of Capital, character, Capacity (ability to repay principal and installments), Collateral, and Condition of Economic (condition of the business economy)". MSMEs need funds to increase their capacity to compete in the ASEAN Economic Community (AEC) itself. Difficulties in obtaining credit from banks make it difficult for MSMEs to compete in the MEA. They consider that in the MEA free trade, MSME products from Southeast Asian countries will enter the Indonesian market. The MEA competition creates a highly competitive climate. Indonesian MSMEs must not lose to compete in terms of quality and quality in competition with MSMEs in Southeast Asian countries.

According to [4], The government facing the ASEAN Economic Community must improve and facilitate access to MSME financing so that MSME products can compete with the quality of MSME products in Southeast Asian countries and penetrate the international market. It will be tough for MSMEs to obtain funds directly from banking. MSMEs can easily access credit through cooperatives. Cooperatives can help MSMEs, considering that through linkage program financing (executing schemes), Cooperatives can provide funding to MSMEs whose funds come from banking. Banks based on this have an essential role in lending to MSMEs. However, the $5 \mathrm{C}$ principle is not a problem for medium-sized businesses, meaning that it can easily be fulfilled because they already have experience as a small entrepreneur. But for small and micro enterprises, the $5 \mathrm{C}$ analysis is complicated because small and micro-businesses lack capital, 
Human Resources (HR), market access, and minimal accounting knowledge that business actors must own.

MSMEs can become part of the cooperative itself to obtain the funds needed to improve the quality of goods and services for the MSMEs themselves. Or several MSMEs can merge into one collective so that its members have firmly held responsibilities because they have a high awareness of developing the cooperative. According to [5], The existence of cooperatives is an internal part of the national economic system, so cooperatives are fundamental in efforts to grow and develop economic potential; apart from banks, cooperatives are also one of the economic veins of the Indonesian nation. Cooperatives have a fundamental role in promoting financial independence. They have become the mainstay of the middle and lower levels of society in improving the economic welfare of the community, as well as in assisting the development of the MSME sector, which has a contribution to reduce unemployment, fight poverty, and create superior products that have local wisdom that has economic value. It may also be possible for several MSMEs operating in the same sector to form a cooperative to obtain ease of credit from banks.

Cooperatives were chosen to provide MSME bank credit because cooperatives are business entities consisting of individuals or legal entities based on their activities based on cooperative principles and a people's economic movement based on the principle of kinship as regulated in Law Number 25 of 1992 concerning Cooperatives. According to [6], Cooperatives can help MSME business actors get credit from banks considering that banks can provide credit to cooperatives with a linkage program. They believe that the Linkage Program is a government policy that provides opportunities for cooperatives to cooperate with commercial and Islamic banks in managing and seeking credit. Whose technical provisions are regulated in the Regulation of the Minister of Cooperatives Number 3 of 2009, which governs three payment patterns, namely (a) Executing, (b) Channeling, (c) Joint Financing?

According to [7], The cooperative is given a loan directly by the bank to finance its members until the cooperative is large and can provide loans to banks. So, the collective is expected to be big enough to be able to offer loans to its members with the Linkage Program. Cooperatives as a form of people's economy do not place economic liberalization as an ideological contradiction but position them as compatible in an open and free-market structure. It isn't easy to imagine when Indonesia enters economic liberalization without cooperatives.
In the MEA era. However, there are concerns that the MEA will not be able to dominate the AEC market. MSME actors who have to deal directly with entrepreneurs from other countries will face problems, especially in terms of capacity building, access to capital and alternative funding, access to technology, standardization, and marketing strategies that are more expensive than Malaysia, Singapore, Brunei, or Thailand which are the main competitors. Therefore, cooperatives can act as an aggregative force that strengthens the bargaining position of national products in the domestic market or foreign markets. If cooperatives are ignored in national economic policies, it is undoubtedly a wrong action and is not in line with efforts to strengthen the competitiveness of national businesses.

Cooperatives that can play a role in economic policy have a strong ideological character and enforce superior management. Considering that Indonesia is part of AFTA, and AFTA uses the Common Effective Preferential Tariffs for ASEAN Free Trade Area (CEPT-AFTA) scheme, to achieve a reduction in tariffs of up to $0-5 \%$, the elimination of quantitative restrictions, and other non-tariff barriers to goods and services from other countries. -Southeast Asian countries.

According [8] This CEPT-AFTA scheme resulted in an agreement to eliminate all import duties on imports of goods for Brunei Darussalam, Indonesia, Malaysia, the Philippines, Thailand, and Singapore in 2010, as well as for Cambodia, Laos, Vietnam, and Myanmar in 2015. If Indonesian MSMEs are not ready to face this MEA, Indonesian MSMEs will lose competitiveness with MSMEs in Southeast Asian countries. Therefore, these SMEs need to be given more attention from the government.

\section{LITERATURE REVIEW}

\subsection{Definition of Bank}

According to Article 3 of the Banking Law, the primary function of Indonesian Banking is to collect and distribute public funds. This means that banks are required to play a more active role in extracting funds from the public in national development [9]. According to the provisions of Article 4 of the Banking Law, the purpose of Indonesian banking is to support the implementation of national development in the context of increasing equity, economic growth, and national stability to improve the welfare of the people at large. With due observance of the precautionary principle, it is hoped that in carrying out its business, Indonesian banks 
will protect the interests of the depositor of funds in particular and support economic activities. The Banking Law states that a bank is a business entity that collects funds from the public in the form of deposits and distributes them to the people in the form of credit or other documents to improve the standard of living of the people at large. Based on the description above, banks are closely related to money circulation activities to facilitate all public financial activities. Thus, the bank functions as:

a) Money lenders are vehicles that can collect and distribute public funds effectively and efficiently. The bank becomes a place for the safekeeping and storage of money, which is a sign of the safekeeping and depositing of the capital, so the depositor and depositor are given a piece of proof paper. Whereas in its function as a distributor of funds, the bank provides credit or buys it in the form of securities.

b) Institutions that carry out trade transactions and payment of money. Banks act as a liaison between one customer and another customer if both make transactions. In this case, the two parties do not directly make payments but instruct the bank to complete them.

\subsection{Cooperative}

Cooperatives are one of the most concrete forms of joint effort. The practice of cooperative kinship principles can be seen from the principles that exist in cooperatives. The unified code is a unity and cannot be separated in communal life. By implementing all these principles, the Cooperative manifests itself as a business entity and a people's economic movement with a social character. In general, the cooperative management principles further elaborate on the kinship principles they adhere to. The consumption cooperative developed the history of the collaborative tenets in Rochdale.

\section{RESEARCH METHODS}

Bandung and two cooperatives, namely the Mitra Kelapa Producer Cooperative, Pangandaran Regency, and the Laladon Ornamental Fish Cooperative, Bogor. The method used for writing this journal is normative juridical. The type of normative legal research aims to assess the quality of the legal norms themselves so that normative legal research is often classified as qualitative research. Data analysis was carried out using a qualitative juridical analysis method, namely the data that had been obtained; the investigation and analysis were carried out to reveal the existing reality with the results of the study with explanations that could not be realized in the form of numbers which the author analyzed at one of the state-owned commercial banks in the City.

The specifications of this research are descriptive-analytical, which is to describe the data as they are and then analyze the data based on the relevant rules regarding DISTRIBUTION OF BANKING CREDIT TO MSMES WITH LINKAGE PROGRAM WITHIN THE FRAMEWORK OF COMPETITIVE MEA COMPETITION. It aims to obtain a comprehensive and systematic picture through an analytical process using legal regulations, legal principles, legal doctrine, and legal understanding.

This research material uses secondary data. The secondary data used are primary legal materials and secondary legal materials. Primary legal materials are binding legal materials. In this study, the following primary legal materials were used:

1) 1945 Constitution

2) Law Number 25 of 1992 concerning Cooperatives,

3) Law Number 10 of 1998 concerning Banking on Law No. Law Number 7 of 1992 concerning Banking,

4) Law Number 20 of 2008 concerning Micro, Small and Small Enterprises intermediate,

5) Candy No. 03/Per/M.KUKM/III/2009 General Guidelines for Program Linkage Between Commercial Banks and Cooperatives. Jakarta: State Minister for Cooperatives and Small and Medium Enterprises of the Republic of Indonesia.

In addition, there are secondary legal materials in the form of scientific essays, journals, articles related to the discussion of this research.

1) Data collection technique

Sources of data needed for researchers obtained from library research:

a) Library Research (Library Research). We are collecting data through research on literature and documents to obtain a theoretical basis in the form of opinions or writings of experts or other parties to receive information, both informal provisions and data through official texts.

b) Interview, which aims to obtain primary data from the banking sector regarding the distribution of the Linkage Program with the Executing scheme to cooperatives. 


\section{RESULTS AND DISCUSSION}

\subsection{Implementation of the Linkage Program as access to MSME banking credit is adjusted to the People's Economy as stated in Article 33 paragraph (4) of the 1945 Constitution}

Cooperatives need special attention, especially as Article 7 of the MSME Law mandates that both the Central Government and Local Governments are required to stipulate laws and policies, one of which includes funding. Financial or financing facilities provided to MSMEs/Cooperatives are in the form of interest subsidies for bank loans, non-bank loans, venture capital, financing, and provision for BUMN profits, grants, etc. One of the Central Government policies is the Ministry of Cooperatives and MSMEs is the Linkage Program.

The rules regarding the Linkage Program are regulated in the Regulation of the State Minister for Cooperatives and Small and Medium Enterprises Number: 03/Per./M.KUMKM/III/2009 concerning General Guidelines for Linkage Programs Between Commercial Banks and Cooperatives. And joint financing.

This financing program implements the mandate of Article 33 of the 1945 Constitution that the national economy is structured based on kinship with cooperatives as the pillars of the national economy. It becomes the primary goal of this linkage program. The financing program is a mandate from Article 22 of the MSME Law, which explains that to increase financing sources for Micro and Small Businesses, the Government makes efforts: Development of financing sources from bank credit and non-bank financial institutions [10].

This linkage program is divided into three patterns: Executing, Channeling, and Joint Financing. In the Cooperatives that the author examines, it turns out that the Channeling pattern is the Coconut Partners Producer Cooperative which is a facilitator between cooperative members and PT Penanaman Madani Nasional. However, it is currently being studied, while the Berkah Bersama Cooperative is a facilitator between cooperative members and PT Antam.

The source of Cooperative Financing that the author studied at the Joint Blessing Cooperative turned out to rely on the partnership development program funds from SOEs, not banks. Meanwhile, KPMK Pangandaran is currently reviewing cooperation with PT PNM and the issue of receiving financing from the partnership development program funds. This is because in banking practice, before providing credit, prospective debtors are required to pay credit administration before being disbursed and the imposition of high-interest rates. Thus, it is considered burdensome for cooperative members than CSR funds from SOEs, where cooperative members are only asked for administrative requirements.

Cooperatives have the function of collecting and distributing funds from members and channeling them to members and the surrounding community. In practice, cooperatives have not been able to maximally carry out the intermediation function, considering that cooperatives have a weakness, namely that the funds they have are limited, considering that the funds come from members of the cooperative, while each member of the cooperative needs funds for their business needs. Therefore, the suitable lacks the capital to run its business. The solution to this problem is that funds are needed from financial institutions to provide credit.

The cooperation between SOEs and cooperatives using CSR funds uses the Community Development Partnership Program scheme. The Community Development Partnership Program manifests BUMN's commitment to developing small and medium enterprises. So that a unit was formed to deal specifically with the development of small businesses. The purpose and objective of the guidance carried out by the PKBL unit for small entrepreneurs is as a forum for BUMN's concern for the development and progress of small entrepreneurs in increasing employment and business opportunities which are expected to improve the welfare of MSME business actors under the auspices of cooperatives.

The author examines that the Coconut Partner Producer Cooperative and the Berkah Bersama Cooperative refuse cooperation with banks, including the People's Business Credit program, considering the high interest charged, the unavailability of collateral owned by the cooperative, and banking administration which requires quite a burden on cooperative members.

High-interest rates have made cooperatives reluctant to cooperate with banks. It's a shame because the banking linkage program is a beneficial partnership for the parties involved, especially for the banking sector. The linkage program can help cooperatives for commercial banks with limited network and infrastructure so that cooperatives can face obstacles in carrying out business development activities for export. Such as the Berkah Bersama Cooperative, which can buy good equipment for 
farming and equipment for exporting fish, and the Coconut Partners Producer Cooperative to procure tools to increase the number of cocopeat and coco fiber for export to destination countries.

The cooperative lacks the capital to run its business. The solution to this problem is funding from financial institutions to grant credit. As explained on the previous page, the cooperative financing in the Berkah Bersama Cooperative uses partnership development program funds, while the Coconut Partner Producer Cooperative is still in the learning stage of cooperation with PT Pegadaian and PT Pegadaian.

The implementation of financing for the Cooperatives that the author studied at the Pangandaran Coconut Partner Producer Cooperative in Pangandaran and the Berkah Bersama Cooperative in Bogor relied on the funding through partnership development program funds originating from State-Owned Enterprises (BUMN). The Pangandaran Coconut Partner Producer Cooperative is currently reviewing the financing cooperation with PT Pegadaian and PT Penanaman Madani Nasional (PNM). The Berkah Bersama Cooperative is undertaking financing cooperation from PT Antam. Because association with BUMN in terms of financing has the advantage that it can be given new credit with the same guarantee. And the calculation of credit provided by PT Antam is more significant than the bank itself.

The legal basis for providing credit that PT Antam distributes to the Berkah Bersama Cooperative and PT Pegadaian and PT Penanaman Madani Nasional if KPMK Pangandaran is interested in financing cooperation is the mandate of Article 2 of the Regulation of the Minister of SOEs Number PER/05/MBU/2007, which states that Persero and Perum are required to implement the BUMN Partnership Program with Small Business and the Community Development Program.

Limited Liability Companies in this case are PT Antam, and PT Pegadaian, PT Penanaman Madani Nasional (PMN). Meanwhile, the Public Limited Liability Company can carry out the BUMN Partnership Program with Small Businesses and the Community Development Program based on the SOE Ministerial Regulation 5/2007, which is stipulated based on the decision of the GMS.

The granting of credit from CSR funds carried out by SOEs uses the Partnership Program Fund with Small Business schemes. This program is a program to improve the ability of small businesses to become strong and independent through the use of BUMN funds based on Article 1 point 6 of the
Regulation of the Minister of BUMN Number PER/08/MBU/2013.

Providing credit assistance, especially for working capital that SOEs manage, is a significant factor in advancing the community's welfare, especially the lower middle economic community. Especially for cooperatives that need funds for business purposes and the interest of their members. Credit that has been issued in the form of lending to the public is expected to be returned in a short time through repayment or repayment of credit loans.

The credit returned from the credit loan will be used again for the following credit loan. The money will rotate every period to help improve community welfare through cooperatives.

Cooperatives do not have collateral, so it is challenging to establish cooperation with banks using Executing and Joint Financing patterns. As it is known that the building of KPMK Pangandaran does not stand with its Ownership Certificate and the Joint Blessing Cooperative stands on land owned by the Bogor Regency Government. Therefore, the channeling pattern is used where cooperatives act as facilitators so that cooperative members recognize the precautionary principle known as the 5C principle, namely Character (character), Capacity (ability to repay the debt), collateral (collateral), Capital (capital), and Condition (situation), and conditions).

Cooperatives practice being able to choose cooperative members who meet the requirements with this $5 \mathrm{C}$ principle, whether it is for collecting contributions, supervising, and teaching members to resolve disputes if problems occur. Implementation of this pattern, the result is an increase in the ability of cooperatives about $5 \mathrm{C}$ analysis.

The author examines that it turns out that those who collaborate with cooperatives in terms of financing are not from banks but state-owned enterprises using Corporate Social Responsibility (CSR) funds. Considering that the interest offered by banks is large enough that CSR funds from SOEs are looked at to cooperate, this is seen considering that the CSR funds that are given interest are less, namely $3 \%$. In contrast, at least less than $7 \%$ is charged with an administration fee of $\mathrm{Rp}$ from banks alone. Rp. 840,000.00 (eight hundred and forty thousand rupiahs), new credit can be given with the same guarantee. Even the cooperative was rewarded, promoted, and included in exhibitions whose operational costs were borne by the BUMN.

Banks as agents of development should play a more active role than SOEs in lending. This is because Indonesian Banking has an intermediary 
function based on Article 3 of the Banking Law, collecting and distributing public funds. This means that banks are required to play a more active role in extracting funds from the public in the context of national development. One of the national developments is through the provision of credit to cooperatives because it is for banking, namely to improve the welfare of the people, in this case, cooperatives formed by SMEs.

According to the provisions of Article 4 of the Banking Law, the purpose of Indonesian banking is to support the implementation of national development in the context of increasing equity, economic growth, and national stability to improve the welfare of the people at large. By paying attention to the precautionary principle, it is hoped that in carrying out its business, Indonesian banks will protect the interests of the depositor of funds in particular and support economic activities in general.

The banking sector has an essential role in Economic Development as for the targets to be achieved in increasing equity and economic growth that are inclusive and in favor of the poor and vulnerable, as stated in Book II of the Development Agenda for the 2015-2019 National Medium-Term Development Plan (RPJMN).

The development of a nation, including economic development, requires the participation of financial institutions to finance it because the story involves the availability of funds. Therefore, the existence of financial institutions in financing development is essential.

Indonesian banking has a strategic objective in increasing national economic stability. There is a need for a national economy. In increasing national strength, there is a need for regularity. Therefore, banking in terms of national stability, such as social, requires cooperatives.

According to [11], cooperatives were established as an alliance of the weak to defend their necessities of life. Achieving the conditions of life at the lowest possible cost is the goal. In cooperatives, everyday needs are prioritized, not profits, considering that the purpose of cooperatives is to improve the welfare of the community.

Social stability will be fulfilled if the community's welfare is met; therefore, the role of banks is needed to channel low-interest loans to cooperatives so that cooperatives can develop their business capacity and prosper their members, who are MSME business actors.
One of the points in Book II of the Development Agenda for the 2015-2019 National Medium-Term Development Plan (RPJMN) is the increasing access of micro and small businesses to opportunities for skill development, mentoring, business capital, and technology development. Therefore, banks need to reduce the KUR interest charged, considering that business capital is necessary for MSMEs. Considering that banks, especially state-owned banks, in this case, one of them is BRI (Bank Rakyat Indonesia).

BRI itself, in this case, the provision of credit, functions as a bank for managing local government credit to the community (Channeling Bank). The types of businesses financed by this PER Credit are productive businesses carried out by small and household entrepreneurs and cooperatives in all economic sectors. In practice, the term credit is also used for the delivery of money so that if we use the words credit, this term includes a consensual credit agreement or an accurate handover of cash.

The credit agreement agrees on each party's rights and obligations, which will become law for the parties who make it. This principle forms a contractual relationship and places the rights and obligations of the parties by the mutually agreed upon. Credit agreements are not explicitly regulated in the Civil Code or the Banking Law.

A credit agreement in banking practice is an unnamed agreement. Based on Article 1338 paragraph (1) of the Civil Code, which is known as an article containing the principle of freedom of contract. The credit agreement between the bank and the debtor is based on the agreement between the parties, namely the agreement between the bank as the creditor and the debtor. The Banking Act does not provide an understanding of credit agreements, so it does not determine the form of credit agreements.

The form and material of the credit agreement between one bank and another are not the same. This happened to adapt to the needs of each bank. Thus, the credit agreement does not have a generally accepted form. Credit agreements are usually stated in written form and standard agreements in banking practice. Credit agreements often accommodate, such as other things, the determination of loan interest and penalties if the debtor is negligent and various other clauses, including penalties imposed.

The limitations, in this case, are the imposition of interest and the reduction of even omitted administrative costs to the cooperative members, which will undoubtedly help the cooperative. This, of course, in addition to assisting the Cooperatives, 
on the one hand, also supports the banks themselves in carrying out their role as Agents of Change through written credit agreements.

The practice of this banking credit agreement is based on the provisions of Presidential Instruction No. 15/IN/1066 concerning Policy Guidelines in the field of Credit in conjunction with the Circular Letter of Bank Indonesia Unit I No. 2/539/UPK/Pemb, and Circular Letter of Bank Negara Indonesia Unit I No. 2/649/UPK/Pemb, as well as Cabinet Presidium Instruction No. 10/EK/2/1967 which states that banks are prohibited from providing credit in various forms without an explicit credit agreement between the bank and the customer. In addition, the practice of bank credit agreements is emphasized that they must be in written form. This is based on the Decree of the Board of Directors of Bank Indonesia No. 27/162/KEP/DIR and Bank Indonesia Circular No. 27/7/UPPB concerning Obligations to Prepare and Implement Bank Credit Policies for Commercial Banks which states, that every credit that has been approved and agreed upon by the credit applicant is expressed in a written credit agreement. The credit applicant, in this case, is a member of the cooperative; of course, it is necessary to accommodate the conditions that burden the joint member, such as reduced interest and even administrative costs that do not need to be withdrawn.

Banks as intermediary institutions must play a more active role considering that the Government has issued a KUR program. KUR is a particular credit/financing scheme intended for MSMEs and cooperatives. Their businesses are viable but do not have sufficient collateral according to the requirements set by the banking system.

The KUR program is to help MSMEs gain better access to bank credit as a form of application of government policies by accelerating the development of the real sector and empowering MSMEs. KUR requirements from Bank BRI are Working Capital and Investment Credit with a ceiling of up to IDR 25 million per debtor. With credit terms, the maximum amount of credit is IDR 25 million per debtor.

Type of credit:

- Working Capital Credit (KMK) for a maximum period of 3 (three) years

- Investment Credit (KI) with a full term of 5 (five) years

- The interest rate is $7 \%$ effective per year or equivalent to $0.41 \%$ flat per month No fees and administration fees.
However, in reality, the Berkah Bersama Cooperative prefers financing from PT Antam over KUR with Bank BRI because the interest offered by Bank BRI is high at $7 \%$ compared to PT Antam itself. Moreover, in taking the contract for the bank, the prospective debtor must pay an administration fee of Rp. 800.000,00. With PT Antam, there is no charge for administration and no penalty and fines. Notably, the funds provided can make the cooperative positively impact its members. Even PT Antam provided its proposal to become a joint member, only preparing the necessary administrative requirements. This shows the inconsistency of banking in helping MSMEs considering that cooperative members in the Berkah Bersama Cooperative are charged an administrative fee.

This is because the Government created the People's Business Credit (KUR) scheme to develop the capacity of micro, small and medium enterprises (MSMEs) more optimally and make it easier for MSMEs to get credit from banks. The KUR financing credit system with a legal relationship agreement between the creditor is a bank and the debtor is a cooperative/MSME. The issue of interest can be negotiated regarding the imposition of interest so that cooperatives are not challenging to cooperate with banks.

This condition cannot be separated from the many classic problems that MSMEs, including the MSME sector, often face, are not bankable, so funding escalation is often constrained, primarily related to additional collateral requirements. The ultimate goal of launching the KUR program is to improve the economy, alleviate poverty, absorb labor, and increase the capacity of Cooperatives in terms of disbursing funds to expand business activities in terms of exports aimed at the welfare of its members. An example is the Coconut Producer Cooperative Partners in implementing the Coconut Garden Revitalization program, which aims to assist coconut farmers in helping them from the trap of coconut dealers.

The Idjon system, better known as the pawn system in Pangandaran Regency, is very burdensome and burdensome for coconut farmers. Moreover, the guarantee of the debt is the coconut. As long as the farmers have not paid off the debt, the coconut dealers will continue to take the coconut fruit without reducing the debt yield.

It is difficult for coconut farmers to survive in such conditions if the coconuts are harvested continuously. Therefore, the cooperative undertakes a business, namely the Revitalization of Coconut Gardens. For this reason, the joint distributes loans 
to farmers to redeem the pawned plantations to the dealer/middleman. Next, the farmer repays the loan to the cooperative with the yields obtained. The program has been implemented for 15 farmers who are members of the cooperative.

Banks' role is vital in lending to cooperatives to help MSMEs. In addition to the revitalization of coconut plantations, KPMK Pangandaran, of course, in coconut processing, of course, requires the procurement of tools to increase the number of various processing plants.

The cooperative, of course, requires bank credit, according to the analysis of the author of KPMK Pangandaran, to be able to carry out the Linkage Program with the Joint Financing scheme by implementing the Coconut Plantation Revitalization program. However, it is hampered, considering that the banking sector asks for collateral in the form of land assets with title rights. At the same time, KPMK Pangandaran does not have investments in the form of ownership certificates.

\subsection{The Government's efforts to improve the competitiveness of MSMEs in the context of the ASEAN Economic Community competition}

The central concept of the AEC is to create ASEAN as a single market and unified production base. This single market will create a free trade flow in goods, services, capital, and investment. There is a free flow of goods, services, factors of production, acquisition, and money, and the elimination of tariffs for trade between ASEAN countries.

As an ASEAN member country with the largest population, Indonesia will potentially become a substantial market for trade in goods and services produced by ASEAN countries. With the assumption, the free market will encourage each ASEAN country to perform optimal efficiency and ultimately improve the people's welfare. The ASEAN Economic Community is also expected to become the backbone of the economy that can compete with China and India.

A cooperative requires the correct competitive strategy to survive in the competitive arena. A collective will be able to win the match if the company has a competitive advantage so that the company is seen as more than its competitors by the community. In recent times, business competition in the competitive and global AEC has forced Cooperatives to be genuinely competitive in efficiency, innovation, pricing, and business development. The level of competition is getting sharper in line with the increasingly rapid flow of information and the rapid growth of technology.

MSMEs in Indonesia has a GDP contribution of $59.08 \%$ of $4,869.5$ trillion/year and absorb a workforce of $97.16 \%$ or as many as $107,657,509$ people. MSMEs are always described as a sector with an important role because most of the population has low education and lives in smallscale business activities, both in the traditional and modern sectors. So that MSMEs play a vital role in economic development and growth, not only in developing countries but also in developed countries. It is widely recognized that MSMEs are essential because of the main characteristics that distinguish them from large enterprises, especially because MSMEs are labor-intensive enterprises, exist in all locations, especially in rural areas, are more dependent on local raw materials.

In addition, MSMEs also have relatively strong resilience to the economic crisis, as during the financial crisis that occurred in 1997-1998, in which conditions at that time small, micro, and medium enterprises proved to be more immune than large companies experienced bankruptcy. This is where MSMEs can show their vital role by maintaining their existence.

This will also be an opportunity and a challenge for the products produced by MSMEs in Indonesia. In this case, increasing the competitiveness of SMEs is a critical factor in being able to face challenges and take advantage of opportunities from the existence of the MEA. Therefore, MSMEs formed cooperatives to compete in the MEA. They consider that by creating a Cooperative, MSME business actors are given the convenience of cooperating with any party. This situation encourages every cooperative to strive to increase competitive advantage, among others, by producing products that can meet the needs and satisfy the desires of buyers who are increasingly aware of the importance of the quality of the products they buy.

Cooperatives cannot operate on their own; therefore, the private sector, universities, local governments, and the community must work together to be competitive. This approach is known as the Quadruple Helix approach. This approach can improve the quality and quality of MSMEs who are cooperative members. This Quadruple Helix involves academia, companies, governments, and communities. The Quadruple Helix approach is expected to be one of the tools used to build and increase the capacity of MSMEs. 
Academics are concerned with contributing creative ideas and the latest research and development results so that the production results of cooperatives become innovative and exciting. Not only that but coupled with conducting training and management guidance to cooperatives regarding cooperative administration. The private sector provides the necessary conditions for an integrated innovation ecosystem. The government provides the regulatory framework and financial support for implementing innovative strategies and policies. Civil society as users/consumers are expected to immediately realize the importance of using domestic products so that foreign products will be increasingly difficult to compete with household products.

The quadruple Helix approach is critical to use in a cooperative. In addition, the Cooperative has also developed various processed coconut products so that they can be processed into quality products. For example, the top export product is Coco fiber, and Coco peat is exported to China, Canada, and Sri Lanka. Currently, KPMK Pangandaran is preparing for Coconut Flour to be shipped to Canada, where the private sector assists the implementation of the cooperative's export.

The capacity building of MSMEs in the Coconut Partner Producer Cooperative is analyzed using the Quadruple Helix, which involves the roles of companies, universities, communities, and local governments, namely:

The company, in this case, PT Pegadaian and PT Permodalan Madani Nasional, provided the capital;

Higher Education, in this case, is the Faculty of Economics, the University of Padjadjaran, which provides technical and administrative assistance in the management of cooperatives;

In this case, the Regional Government of Pangandaran Regency assists the Pangandaran KPMK Cooperative, and one of them is to introduce superior products from KPMK Pangandaran.

The community, in this case, is the end-user of the Pangandaran KPMK product.

It is not surprising that now KPMK is one of the successful cooperatives in exporting. KPMK Pangandaran already has a broader collaboration. KPMK Pangandaran is currently collaborating with various companies to carry out domestic buying and selling activities and exports of coco fiber and coco peat. In the future, KPMK Pangandaran will create a business unit in the form of a Limited Liability Company in business development, especially in terms of exports. The Cooperative has the characteristics of a Limited Liability Company prioritizes professionalism, profit orientation, and business development.

The Quadruple Helix approach at KPMK Pangandaran has not been maximized, considering that the Regional Government, Universities, and Companies have not implemented the Quadruple Helix concept effectively. If the Regional Government and Universities cooperate, it is possible that KPMK can be more advanced than before. If the Mitra Kelapa Producer Cooperative can develop its products and quality, then the CSR funds lent to the Cooperative can improve the welfare of coconut farmers and increase the volume of exports of superior products to destination countries. It is different from the Joint Blessing Cooperative.

The Berkah Bersama Cooperative, previously a community assisted by the UPT Center for Animal and Fish Health Center (Puskeswankan) Region VI, Department of Animal Husbandry and Fisheries, Bogor Regency facilitated other farmer groups to trade around the UPT office located in Laladon.

This Cooperative is in terms of technical development of ornamental fish, which is the authority of the Bogor Regency Fisheries Service. In trading activities, it is under the guidance of the Bogor Regency Trade Office. The Department of Cooperatives and SMEs institutionally assists this Cooperative in Bogor Regency.

The Cooperative's members carry out trading activities, while the cooperative acts as marketing and promotion. However, the role of universities is minimal or even non-existent institutionally. This can hinder the development of cooperatives, considering that these cooperatives require knowledge in the ornamental fish market, mainly the decorative fish market export. They think that the cooperative must cultivate ornamental fish, which requires a particular place or farming to export activities to Dubai.

The role of the government is very much needed in the development of exports carried out by the Berkah Bersama Cooperative. To get special attention from the Bogor Regency Government, at the time of shipping the fish, the Cooperatives invited the Bappeda and related agencies to show that in carrying out their export activities, the Cooperatives needed assistance and requests for facilities from the local government. One of them is the Good Fish Quarantine Method (CKIB) which assesses it is from the Fish Quarantine, Quality Control and Safety of Fishery Products, which 
concerns biosecurity, packaging, and the place for fish used to be prepared for export packaging.

The role of the Regional Government of Bogor Regency is very much needed in the request for these facilities considering that the Cooperative requires special attention considering the Berkah Bersama Cooperative is the only ornamental fish exporter in Indonesia that exports the ornamental fish to Dubai. Micro and small businesses that are members of this cooperative to compete well must be given training and coaching to develop their business so that the production process can produce products that comply with global standards such as Quality Issues (ISO 9000), Environmental Issues (IS0 14000). So that in the future, Dubai will not only be the destination for ornamental fish exports from the cooperative but also various countries. So, therefore, Micro and small businesses in these cooperatives need to be given training and guidance so that they can compete in facing the MEA and APEC. In addition, the Bogor Regency Government and the Pangandaran Regency Government need to coordinate with the West Java Provincial Government so that the West Java Provincial Government provides information on international markets to expand the export destination countries of the Cooperative so that the Cooperative can be export-oriented. In particular, the Berkah Bersama Cooperative in exporting ornamental fish is not only Dubai, which is a destination for ornamental fish exports. The Bogor Regency Government and the Pangandaran Regency Government need to coordinate with the West Java Provincial Government. The West Java Provincial Government provides information on international markets to expand the export destination countries of the Cooperative so that the Cooperative can be export-oriented. In particular, the Berkah Bersama Cooperative in exporting ornamental fish is not only Dubai, which is a destination for ornamental fish exports. The Bogor Regency Government and the Pangandaran Regency Government need to coordinate with the West Java Provincial Government. The West Java Provincial Government provides information on international markets to expand the export destination countries of the Cooperative so that the Cooperative can be export-oriented. In particular, the Berkah Bersama Cooperative in exporting ornamental fish is not only Dubai, which is a destination for ornamental fish exports.

The role of government is proportionally a common phenomenon in economic development in developing countries. The government's position as a regulator, motivator, facilitator, initiator, and protector for the growth of creativity and economic efficiency, and marketing intelligence.

The government's role can be reviewed based on two perspectives, namely, the perspective of competitiveness and the perspective of creative power. If viewed from the perspective of increasing competitiveness in the global economy, it is manifested in the form of, among others: Creating an institutional structure that is integrated with market competition and supports macroeconomic reform; Ensure legal certainty to convince investors; Formulate and implementing policies that support the development of private enterprises; Maintain exchange rate stability; Implement educational controls that help productivity.

Universities need to be involved in the development of the Joint Blessing Cooperative. They consider that the cooperative requires knowledge in the development of ornamental fish, such as the development of new cosmetic fish genetics. So that the ornamental fish produced are more attractive than ornamental fish from ASEAN countries in particular. So innovation, product innovation, and production process have not been maximized and even does not exist given the absence of a cooperation agreement in business development. So, therefore, It is essential for universities because universities have academics who have qualified expertise in terms of cooperative development considering the contribution of creative ideas and the latest research and development results so that the production of ornamental fish becomes innovative. The durability of ornamental fish becomes better considering that if ornamental fish are exported, they will fast first because the ornamental fish will take two days to arrive in Dubai. Not only that but by conducting training and guidance to cooperatives to carry out research results from what has been done by academics.

The Quadro Helix approach plays a vital role in cooperatives. If cooperatives are developed with the Quadro Helix approach, cooperative members who are MSME business actors can get protection from government elements both from licensing and export activities, assistance in developing competitive businesses for business progress. From academics and local government regarding technical provisions in ornamental fish cultivation. Which concerns biosecurity, packaging, and fish containers used to be prepared for export packaging. This condition must be fulfilled because if it is not implemented, the fish at the export destination airport can be returned or destroyed. 
Global markets such as Dubai, which the Joint Blessing Cooperative exports, have other challenges. Exporting is not as easy and cheap as entering the domestic market due to risk factors and higher costs. The cost of obtaining an export market is a sunk cost, i.e., costs that must be incurred, and these costs cannot be withdrawn. If the cooperative exports fish without going through reasonable procedures, the fish will potentially be destroyed if the ornamental fish arrive in Dubai.

Quadruple Helix has three stages, including coordination, namely the formation of institutions to help increase the competitiveness of cooperatives, individual performance between universities, stateowned enterprises, and the government, and synergy between the results that have been made by universities, state-owned enterprises, and the government. Based on the results of the author's research, the most appropriate theory is the Theory of Development Law by which is needed in the field. The concrete form is that an Ad-Hoc Institution can directly apply the Quadro Helic Approach in a systematic and structured manner. The Ad-Hoc bodies consist of Universities, Governments, and State-Owned Enterprises. Because if a permanent institution is created, it is feared that it will increase the burden on the state budget, and its implementation function cannot be ascertained.

The role of the private sector or in practice is with State-Owned Enterprises, namely between Cooperatives and State-Owned Enterprises through the Partnership Development Program based on Article 2 of the Regulation of the Minister of BUMN Number PER/05/MBU/2007, which states that Persero and Perum are obliged to implement the Partnership Program BUMN with Small Business and Community Development Program. Partnership Development Program with 3\% interest.

The government between the Regency Government and the Provincial Government itself needs coordination so that each cooperative/UMKM empowerment program itself can be well implemented in the West Java Province Cooperative and SME service programs such as the intimate credit program, MSMEs are promoted, champion entrepreneurs so that each cooperative/UMKM can be oriented. Export. So that unified Indonesian products can compete with foreign products. Therefore, cooperatives that universities assist need to acquire marketing intelligence on a massive scale so that it can be accommodated efficiently and effectively, which refers to international standardization.

\section{CONCLUSION}

1) Implementation of the Linkage Scheme The banking program has not been effective in terms of lending to cooperatives considering the interest rate charged is relatively high, namely $7 \%$ on the legal basis of Article 15 paragraph (2) of the Regulation of the Coordinating Minister for Economic Affairs of the Republic of Indonesia as Chair of the Financing Policy Committee for Micro, Small and Medium Enterprises. Medium Number 11 of 2017 concerning Guidelines for the Implementation of People's Business Credit regarding credit financing to Cooperatives, in addition to that it is subject to an administrative fee of Rp. Default. The Partnership Development Scheme of State-Owned Enterprises is more effective because of its simple administration, like lower interest rates and the absence of fines.

2) The Government's efforts to increase the capacity of Cooperatives, Cooperatives can increase capacity by using the Quadro Hellix approach in expanding the capacity of Cooperatives to create cooperatives that have positive competitive capabilities in facing the ASEAN Economic Community. Considering that cooperatives are not only the government's responsibility but awareness or moral awakening of all parties to help cooperatives, the Quadro Hellix approach involves several elements such as academia, government, private sector, and the community. Academics, in this case, are universities that provide technical and administrative assistance in the management of cooperatives; The government acts as a regulator and facilitator, in this case giving service to cooperatives. One of them is introducing superior products from cooperatives formed by MSME actors. Nongovernmental organizations, in this case, are groups of community activists who provide input and advice to coconut farmers to establish cooperatives. The strengthening through the Quadruple Helix is expected to encourage micro and small businesses to grow into companies with a larger business scale and contribute more to creating added value. Cooperatives are also likely to play a more significant role in improving the business system of members of micro and small businesses, strengthening the domestic market, and developing partnerships and business networks based on value chains and supply chains. Increasing the competitiveness of SMEs and cooperatives is also expected to 
increase their capacity to respond to market changes and an increasingly dynamic economy in the face of the ASEAN Economic Community and can make cooperatives compete in free cross-border trade with foreign companies.

\section{AUTHORS' CONTRIBUTIONS}

JL and UBJ collect the material and analyze the data provided by JL and UBJ collect data from various literature and data.

\section{REFERENCES}

[1] Goverment of Indonesia, Undang-Undang Dasar Negara Republik Indonesia 1945. Indonesia, 1945.

[2] Rudyanti Dorothea Tobing, Aspek-Aspek Hukum Bisnis Pengertian Asas Teori dan Praktek. Surabaya: Laksbang Justitia, 2015.

[3] E. Mulayati, Kredit Perbankan (Aspek Hukum dan Pengembangan Usaha Mikro Kecil dalam Pembangunan Perekonomian Indonesia), vol. 1, no. 2. 2016.

[4] Huala Adolf, Prinsip Hukum Perdagangan Internasional Kebijakan Subsidi dan UMKM. Bandung: Rafika Aditama, 2018.
[5] G. Kartasapoetra, Koperasi Indonesia yang Berdasarkan Pancasila Dan UUD 1945. Jakarta: PT. Rinerka Citra, 2001.

[6] Tarsisius Murwadji dan Ahmad Hagi Robby, "Edukasi dan Penyehatan Koperasi Melalui Linkage Program Perbankan," Padjadjaran J. Ilmu Huk., vol. 4, p. 454, 2017.

[7] Rio Wilantara dan Susilawati, Strategi \& Kebijakan Pengembangan UMKM Upaya Meningkatkan Daya Saing UMKM Nasional di Era MEA. Bandung: PT Refika Aditama, 2016.

[8] Afta, "ASEAN Free Trade Area (AFTA) Council."

https://asean.org/meetingreportparent/asean -free-trade-area-afta-council/ (accessed Nov. 20, 2021).

[9] Goverment of Indonesia, Undang-Undang Republik Indonesia Nomor 10 Tahun 1998 Tentang Perbankan. Indonesia, 1998.

[10] Goverment of Indonesia, Undang-Undang Nomor 20 Tahun 2008 Tentang Usaha Mikro Kecil Menengah. Indonesia, 2008.

[11] Sonny Sumarsono, Manajemen Koperasi. Jember: Graha Ilmu, 2008. 